\title{
RESEARCH ON WINE PRODUCERS IN NORTH CENTRAL REGION OF BULGARIA
}

\author{
I. Georgiev ${ }^{1 *}$, P. Midova ${ }^{2}$ \\ ${ }^{1}$ Shato Danubia AD, Russe, Bulgaria \\ ${ }^{2}$ Department of Commerce, Faculty of Industry and Commerce, D. A. Tsenov Academy of \\ Economics, Svishtov, Bulgaria
}

\begin{abstract}
Viticulture is one of the priorities of European agricultural policy. The sale of wine is successful when the product offered is competitive in the relevant market. The qualities of wine as a specific product are determined by the following factors - grape variety, wine taste, ecology of the region, wine production technology, etc. In this sense, Bulgaria has all the prerequisites for being among the leading wine producers in Europe and in the world. Our country has a tradition in the vine and wine sectors, in which funds continue to be invested. This is the main reason for the study to be focused on the wine market.

The main objective of the scientific research paper is to outline the role of wine production in Bulgaria and to study sales in one of the wine regions - North Central.

The subject of the study is the producers from the wine-growing region, members of the National Vine and Wine Chamber. In this regard, the survey was conducted in four of the seven companies, namely: Vinal AD., Lovech; Winery Pleven EAD, Pleven; Winery Svishtov AD., Svishtov and Loviko Lozari, Suhindol.

The object of the study is the market indicators of the wine producers in the selected region. These indicators are being summarised and analysed. In conclusion, trends are outlined and recommendations for improving the efficiency of the surveyed enterprises in the sector are derived.
\end{abstract}

Key words: wine producers in the North Central Region of Bulgaria, net sales revenues, market share and relative market share of wine producers, net sales revenue per employee.

\section{INTRODUCTION}

In Bulgaria, there are favourable climatic conditions for the development of viticulture, which require studying the problems of this sector. Characteristic of wine production is its zoning, since the quality of the product depends on the variety of grapes from which it is obtained. In this regard, the geographical features of the region predetermine the grape varieties and the qualities of the wine grown there.

The present study examines part of the wine producers in the North Central Region, occupying 15149 square kilometres or $13.6 \%$ of the country's territory. The region covers Pleven, Lovech, Veliko Turnovo and Gabrovo districts and is the first in the country in arable

\footnotetext{
*Correspondence to: Georgiev, Shato Danubia Ltd., Russe, Bulgaria, e-mail: iliyangeorgiev@abv.bg, mobile phone: +359898870273
}

land. It cultivates varieties such as Gamza, Misket, Dimyat, Pamid, Muscat Ottonel, Merlot, Cabernet Sauvignon, Pinot Noir, Misket, etc.

The wine is both a traditional Bulgarian drink and a drink consumed all over the world. In different countries, the consumption of wine has its own peculiarities, but it can be distinguished by those that are characteristic of this product as a whole. The peculiarities concerning its manufacturers may be summarised as follows:

- wine production has established traditions and culture is formed for its consumption;

- zoning of production related to the requirements for the cultivation of each wine grape variety;

- a technologically complex process and each stage of it requires a certain duration;

- normative regulation of the production activity - in Bulgaria, Wine and Spirit Drinks Act (1); 
- registration of wines according to the national legislation - in our country the Law on Trademarks and Geographical Indications (2);

- good export potential;

- establishing strong brands in the global wine market, including Bulgaria;

- seasonal nature of the product and consumption is year-round.

\section{ANALYSIS OF THE ACTIVITIES OF WINE PRODUCERS IN THE NORTH CENTRAL REGION}

Producers who are members of the National Vine and Wine Chamber are the subject of research. In this regard, the survey was conducted in four of the seven companies,
GEORGIEV I., et al. namely: Vinal AD, Lovech; Winery Pleven EAD, Pleven; Winery Svishtov AD, Svishtov and Loviko Lozari, Suhindol. Data on wine producers are representative of the studied area. The information for conducting the survey is provided by the Annual Financial Statements and the Annual Activity Reports of four companies, as well as specialised literature.

The first indicator is the reporting of net sales revenue (3). The dynamics of the net sales revenues (4) of the studied enterprises for the period 2006 - 2017 are summarised in the following Figure 1.

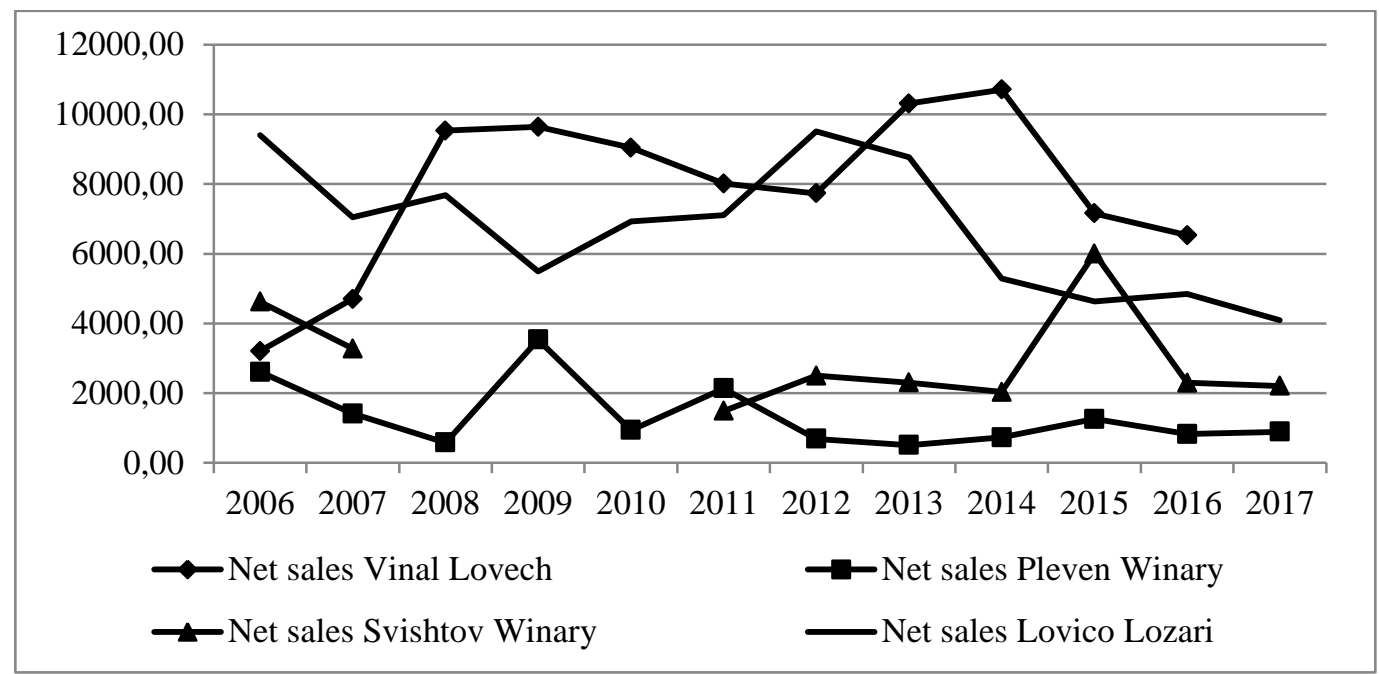

Figure 1. Amount of net sales revenue of Vinal, Winery Pleven, Winery Svishtov and Loviko Lozari for the period $2006-2017$

Source: Developed by the author

Vinal's net sales revenue is the highest during the period under review, the lowest amount is in the first year and then it is increasing fourfold over a two-year period. There was a slight decline in 2012, a peak in 2014 and a decline in 2016 to the amount of over BGN 6000 thousand.

At Winery Pleven net sales revenues are below 2000, peaking in 2009 and reaching almost BGN 4000 thousand. In the next 2010, they fall to almost their minimum levels, and in 2011 they slightly increased to BGN 2000 thousand. After 2012, they have a relatively constant amount of about BGN 1000 thousand. Given the lack of data on a Winery Svishtov, there may be a slight decline in the first two years, holding at relatively the same level after
2011 except in 2015, when they peaked at BGN 6000 thousand.

Net sales revenue is too dynamic with Lovico Lozari. The downward trend is in the first four years - from over BGN 9000 thousand in 2006 to below BGN 6000 thousand in 2009, followed by an increase over the next four years - from below BGN 6000 thousand as mentioned above and a return to levels above BGN 9000 thousand in 2012. After this period, there has been a trend of a steady decline to BGN 2000 thousand in the last 2017.

The survey data allow us to take into account the growth of net sales revenue compared to the previous year - Table $\mathbf{1}$ and to the last year - Table 2. 
GEORGIEV I., et al.

Table 1. Growth in net sales revenue of Vinal, Winery Pleven, Winery Svishtov and Loviko Lozari for the period $2006-2017$

\begin{tabular}{|c|c|c|c|c|}
\hline \multicolumn{5}{|c|}{ Growth of net sales revenue in thousands of BGN } \\
\hline Years & 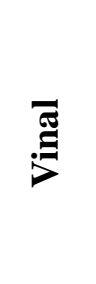 & 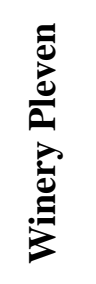 & 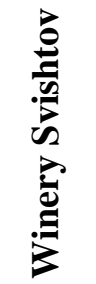 & 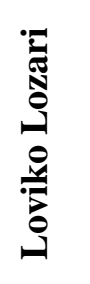 \\
\hline Columns & 1 & 2 & 3 & 4 \\
\hline 2007 & 0.47 & -0.46 & -0.29 & -0.25 \\
\hline 2008 & 1.03 & -0.59 & n.a. & 0.09 \\
\hline 2009 & 0.01 & 5.07 & n.a. & -0.28 \\
\hline 2010 & -0.06 & -0.73 & n.a. & 0.26 \\
\hline 2011 & -0.11 & 1.27 & n.a. & 0.03 \\
\hline 2012 & -0.03 & -0.68 & 0.67 & 0.34 \\
\hline 2013 & 0.33 & -0.26 & -0.08 & -0.08 \\
\hline 2014 & 0.04 & 0.43 & -0.12 & -0.40 \\
\hline 2015 & -0.33 & 0.72 & 1.95 & -0.12 \\
\hline 2016 & -0.09 & -0.34 & -0.62 & 0.05 \\
\hline 2017 & & 0.08 & -0.04 & -0.16 \\
\hline
\end{tabular}

Source: Developed by the author

*n.a. - missing data

Table 2. Growth in net sales revenue of Vinal, Winery Pleven, Winery Svishtov and Loviko Lozari for the period $2006-2017$

\begin{tabular}{|c|c|c|c|c|c|}
\hline \multicolumn{6}{|c|}{ Sales growth (geometric progression) } \\
\hline Years & 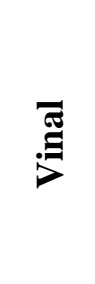 & Years & $\frac{a}{0}$ & 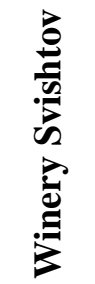 & 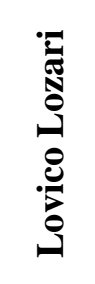 \\
\hline Columns & 1 & 2 & 3 & 4 & 5 \\
\hline $2016 / 2006$ & -0.80 & $2017 / 2006$ & -0.97 & -0.96 & -0.96 \\
\hline $2016 / 2007$ & -0.85 & $2017 / 2007$ & -0.94 & -0.93 & -0.94 \\
\hline $2016 / 2008$ & -0.91 & $2017 / 2008$ & -0.83 & 0.00 & -0.94 \\
\hline $2016 / 2009$ & -0.90 & $2017 / 2009$ & -0.97 & 0.00 & -0.91 \\
\hline $2016 / 2010$ & -0.88 & $2017 / 2010$ & -0.86 & 0.00 & -0.92 \\
\hline $2016 / 2011$ & -0.84 & $2017 / 2011$ & -0.93 & -0.75 & -0.90 \\
\hline $2016 / 2012$ & -0.79 & $2017 / 2012$ & -0.74 & -0.82 & -0.91 \\
\hline $2016 / 2013$ & -0.79 & $2017 / 2013$ & -0.56 & -0.76 & -0.88 \\
\hline $2016 / 2014$ & -0.70 & $2017 / 2014$ & -0.59 & -0.64 & -0.74 \\
\hline & & $2017 / 2015$ & -0.64 & -0.82 & -0.56 \\
\hline
\end{tabular}

Source: Developed by the author 
As indicated by the data in Table 1 for Vinal, the most significant increase was the net sales revenue compared to the previous year in 2008 and less significant - in the first year of 2006. For Winery Pleven, the largest increase was again in 2009 and then in 2011. At Winery Svishtov, the largest increase was in 2015 and less - in 2012. Lovico vineyards recorded the highest growth in 2012 and lower in size before this - in 2010.

The dynamics of growth on a constant basis the last year of the survey is summarised in Table 2. The last year for the enterprise in
GEORGIEV I., et al. Lovech was 2016, and for the other three wine producers - 2017.

According to Table 2, the most significant growth in net sales revenue, compared to the last year, for Vinal was in 2014, for Winery Pleven - in 2013, for Winery Svishtov - in 2014, and for Lovico - in 2015.

The position of the four companies studied and their market share for the period 2006 - 2017 is changing - see Table 3.

Table 3. Market share of Vinal, Winery Pleven, Winery Svishtov and Loviko Lozari for the period $2006-2017$

\begin{tabular}{|c|c|c|c|c|}
\hline \multicolumn{5}{|c|}{ Market share of enterprises for the surveyed region (in\%) } \\
\hline & & & & \\
& & & & \\
Years & & & & \\
& & & & \\
& & & & \\
\hline Columns & $\mathbf{1}$ & $\mathbf{3}$ & \\
\hline 2006 & 16.15195 & 13.14928 & 23.29588 & $\mathbf{4 7 . 4 0 2 8 9}$ \\
\hline 2007 & 28.59662 & 8.603916 & 19.9319 & $\mathbf{4 2 . 8 6 7 5 7}$ \\
\hline 2008 & $\mathbf{5 3 . 5 5 2 7 7}$ & 3.274729 & n.a. & 43.1725 \\
\hline 2009 & $\mathbf{5 1 . 6 2 2 5 8}$ & 18.94077 & n.a. & 29.43665 \\
\hline 2010 & $\mathbf{5 3 . 4 5 4 7}$ & 5.561794 & n.a. & 40.98351 \\
\hline 2011 & $\mathbf{4 2 . 7 1 1 6 7}$ & 11.40435 & 7.960119 & 37.92386 \\
\hline 2012 & 37.82475 & 3.390577 & 12.22663 & $\mathbf{4 6 . 5 5 8 0 5}$ \\
\hline 2013 & $\mathbf{4 7 . 0 8 5 9 6}$ & 2.333973 & 10.528 & 40.05207 \\
\hline 2014 & $\mathbf{5 7 . 0 6 2 9 3}$ & 3.905792 & 10.8435 & 28.18778 \\
\hline 2015 & $\mathbf{3 7 . 5 7 0 8 3}$ & 6.605456 & 31.50577 & 24.31794 \\
\hline 2016 & $\mathbf{4 4 . 9 9 7 2 4}$ & 5.719405 & 15.83517 & 33.44818 \\
\hline 2017 & n.a. & 12.44272 & 30.64852 & $\mathbf{5 6 . 9 0 8 7 6}$ \\
\hline
\end{tabular}

Source: Developed by the author

*n.a. - missing data

According to the data in the previous table, it is clear that the leader for the first two years of the survey is Loviko Lozari, then for the next four years, the leadership is of "Vinal" AD in Lovech. In 2012 and in the last 2017, again, the Suhindol enterprise is a leader. For the period 2013 - 2016, Vinal regains its leadership position. The dynamics in the subsector is mainly due to the amount of grapes produced in the region, which is a major factor in the volume of wine produced.

The leader's followers also change over time. This is evident from Table 4, which calculates the relative market shares of the three enterprises compared to the leader among them. In this regard, the change of positions of the other two companies - Winery Pleven and Winery Svishtov is also of interest. 
GEORGIEV I., et al.

Table 4. Relative market share of Vinal, Winery Pleven, Winery Svishtov and Loviko Lozarifor the period 2006 - 2017 compared to the leader among them for the period 2006 - 2017.

\section{Relative market share of enterprises for the studied region compared to the largest competitor (in coefficient)}

$\begin{array}{ccccc} & & & & \\ \text { Years } & & & & \\ \text { Columns } & \mathbf{1} & \mathbf{2} & \mathbf{3} & \mathbf{4} \\ 2006 & 0.34 & 0.28 & 0.49 & \text { Leader } \\ 2007 & 0 ., 67 & 0.20 & 0.46 & \text { Leader } \\ 2008 & \text { Leader } & 0.06 & \text { n.a. } & 0.80 \\ 2009 & \text { Leader } & 0.37 & \text { n.a. } & 0.57 \\ 2010 & \text { Leader } & 0.10 & \text { n.a. } & 0.77 \\ 2011 & \text { Leader } & 0.27 & 0.19 & 0.89 \\ 2012 & 0.81 & 0.07 & 0.26 & \text { Leader } \\ 2013 & \text { Leader } & 0.05 & 0.22 & 0.85 \\ 2014 & \text { Leader } & 0.07 & 0.19 & 0.49 \\ 2015 & \text { Leader } & 0.17 & 0.84 & 0.64 \\ 2016 & \text { Leader } & 0.13 & 0.35 & 0.74 \\ 2017 & \text { n.a } & 0.22 & 0.54 & \text { Leader }\end{array}$

Source: Developed by the author

*n.a. - missing data

The market follower of Lovico Lozari in 2006 was Winery Svishtov, followed by Vinal. The following year, the two companies change positions and Vinal ranks after the leader. During the four-year leadership period of Vinal from 2008 to 2011, its follower was the company in Suhindol - Loviko Lozari, and Winery Pleven was last in the ranking.

The data for 2012 determine similar positions as in 2007, with the leading one - Lovico Lozari, followed by Vinal, Winery Svishtov and Winery Pleven. The situation is repeated with Vinal's

four-year leadership as a follower for three of the years is Lovico Lozari, and only for 2015 Winery Svishtov is the second.During the last year of the surveyed period, the company in Suhindol is leading on the wine market in the region, followed by Winery Svishtov and Winery Pleven.

The latest marketing metric reflects the net sales revenue per employee (5) - Table 5.

Table 5. Net sales revenue per employee of Vinal, Winery Pleven, Wineri Svishtov and Loviko Lozari for the period 2006 - 2017.

Net sales revenue per employee in thousands of BGN

\begin{tabular}{|c|c|c|c|c|}
\hline Years & 丞 & 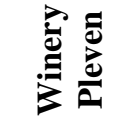 & 党起 & נِ \\
\hline Columns & 1 & 2 & 3 & 4 \\
\hline 2013 & 67.82 & 19.65 & 52.39 & 146.15 \\
\hline 2014 & 70.45 & 28.19 & 46.25 & 88.17 \\
\hline 2015 & 47.11 & 48.42 & 136.48 & 77.25 \\
\hline 2016 & 42.96 & 31.92 & 52.23 & 80.90 \\
\hline 2017 & n.a & 34.46 & 50.16 & 68.30 \\
\hline
\end{tabular}

Source: Developed by the author 
This indicator shows the contribution of each staff member to the increase in sales volume. "By comparing the results obtained by individuals, we can trace the impact of the level of competitiveness available on sales volume" (6).

The data from the table show that the largest sales revenue is provided by the enterprise in Lovech in 2014 and the smallest - in 2016. The Pleven wine producer reports the maximum in this respect in 2015 and a minimum amount in 2013. For the enterprise in Svishtov, the amount of net sales revenue was the highest in 2015 and the lowest - in 2014. At Lovico Lozari in Suhindol, the first 2013 was the strongest, and with the lowest sales revenue per employee - the last 2017.

\section{Trends and Recommendations}

Summarising the results of the analysis of the performance indicators and marketing indicators, it can be concluded that the leaders among the studied enterprises are Lovico Lozari and Vinal. Moreover, Winery Svishtov is ranked in the "golden environment", and Winery Pleven is last in the ranking among the four studied wineries.

Wine producers can focus their efforts in the following areas:

- replacement of aging vineyards with Bulgarian varieties specialised in wine production;

- differentiation of regions with Bulgarian varieties whose qualities are due exclusively to climatic conditions and soils;

- the restoration of traditional wine production in smaller quantities but of higher quality.

\section{ACKNOWLEDGEMENTS}

GEORGIEV I., et al.

This paper is part of the work on Scientific Research Project №5 "Study of the factors influencing wine production in the North Central, South Central and Southeast region", approved by the "Institute for Scientific Research" at the D. A. Tsenov Academy of Economics".

\section{REFERENCES}

1. Wine and Spirit Drinks Act, promulgated in the State Gazette No. 54 of 15.06 .2012 .

2. Law on Trademarks and Geographical Indications, promulgated in the State Gazette No. 58 of 18.07.2017.

3. Iliychovski, S., Filipova, T. Commercial representation and mediation. Comtext Publishing House, Sofia, pp. 232-238, 2013

4. Filipova, T. Implementation of franchising in business (economic and organizational aspects). Tsenov Academic Publishing house, Svishtov, p. 188, 2005.

5. Perkov, V., Midova. P. Sales organization and technology, Faber Publishing House, V. Tarnovo, p. 13, 2013.

6. Nikolova, V. Assessing competitiveness of staff in the trade enterprise. Dialog - E-Journal of Tsenov Academy, Svishtov, 3, 77-110, 2015. 
